\title{
A Revista Portuguesa de Clínica Geral mudou de nome para Revista Portuguesa de Medicina Geral e Familiar
}

Raquel Braga*

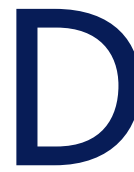

epois da mudança do nome da Associação Portuguesa de Médicos de Clínica Geral para Associação Portuguesa de Medicina Geral e Familiar ${ }^{1}$ é agora a vez de a Revista Portuguesa de Clínica Geral mudar o nome para Revista Portuguesa de Medicina Geral e Familiar. A sua designação abreviada passa a ser Rev Port Med Geral Fam e a designação em inglês Portuguese Journal of General Practice and Family Medicine.

Queremos assinalar a entrada em 2012 com esta mudança na primeira edição do ano, mas, apesar do regozijo com que assumimos a nova denominação, não podemos deixar de recear a confusão e estranheza que esta alteração possa causar aos nossos leitores, sobretudo aos menos assíduos.

Para que não restem dúvidas, a Revista é a mesma, bem como os seus objectivos, a sua missão e o seu Corpo Editorial. Só muda o nome, para outro que se espera mais adequado à maioria dos leitores, à especialidade na qual se enquadra e na qual se revê.

Continuaremos o nosso trabalho com entusiasmo, procurando publicar artigos de qualidade, incentivando sobretudo os originais que expressem a actividade em investigação na Medicina Geral e Familiar Portuguesa e publicando quer em português, quer nas outras duas línguas oficiais da Revista, o castelhano e o inglês. Estamos convictos de que a nossa Revista será tanto mais portuguesa quanto mais lida e citada for no panorama nacional, mas também internacional. A seu tempo, sosseguem os leitores que temem a perda da identidade lusa pela publicação em outras línguas, procuraremos garantir a pos-

* Directora da Revista Portuguesa de Medicina Geral e Familiar sibilidade da publicação simultânea em português dos artigos publicados nas outras línguas oficiais da Revista.

Ao longo do ano de 2011, registou-se um ritmo de submissão de artigos crescente (97 artigos novos), que originou um número de 106 artigos em gestão. Dos artigos em gestão, 37 foram aceites para publicação, tendo a taxa de recusa alcançado os $65 \%$, havendo ainda 26 artigos desse ano em processo editorial. Para a revisão destes artigos contámos com a preciosa colaboração de dezenas de colegas que, amavelmente e de forma generosa, nos ofereceram o seu precioso tempo, saber e perícia, contribuindo, por vezes enormemente, para a melhoria da qualidade dos artigos que publicámos. Da mesma maneira, o seu trabalho contribuiu para a rejeição de uma parte dos artigos submetidos, num formato que esperamos ter sido entendido pelos autores como didáctico e construtivo.

A estes colegas revisores ${ }^{2}$ que, como os editores, trabalham na sombra, não vendo o seu nome associado aos artigos que por vezes tanto ajudam a melhorar, não podemos deixar de transmitir o nosso muito obrigado, publicando neste número, com o respectivo agradecimento, a lista dos seus nomes para, pelo menos uma vez, os isentarmos do anonimato.

Aproveitamos também para agradecer a todos os autores que têm a persistência e a coragem de submeter artigos, sem desmoralizarem perante uma recusa ou um pedido de alteração e também àqueles que, atravessando o difícil processo de revisão, aceitam com empenho e entusiasmo as sugestões de melhoria aos seus manuscritos...

Neste número não podemos deixar também de agradecer a colaboração do Prof. Michael Kidd, presidente 
eleito da WONCA, que aceitou o convite para escrever um Editorial acerca da importância dos relatos de casos clínicos. Este tipo de artigo, que muito nos auxilia na nossa prática clínica diária e cuja publicação temos vindo a incentivar, quer na forma de relato de caso, quer em formato de artigo breve, constitui um importante contributo para o aumento do corpo do conhecimento em Medicina, como o próprio Prof. Kidd refere. ${ }^{3}$

Resta desejar que esta Revista, agora com outro nome, seja cada vez mais forte na sua identidade e que aqueles que a acarinham e conhecem ajudem a refor- çar o valor deste novo nome e a fazer a ponte entre o passado e o futuro.

\section{REFERÊNCIAS BIBLIOGRÁFICAS}

1. Braga R. Um outro nome para uma realidade em mudança. Rev Port Clin Geral 2011 Nov-Dez; 27 (6): 495-6.

2. Agradecimentos aos revisores de 2011. Rev Port Med Geral Fam 2012 Jan-Fev; 28 (1): 71.

3. Kidd M, The Relevance of Case Reports in Family Medicine, Rev Port Med Geral Fam 2012 Jan-Fev; 28 (1): 11-2.

\section{ENDEREÇO PARA CORRESPONDÊNCIA}

director@rpcg.apmcg.pt

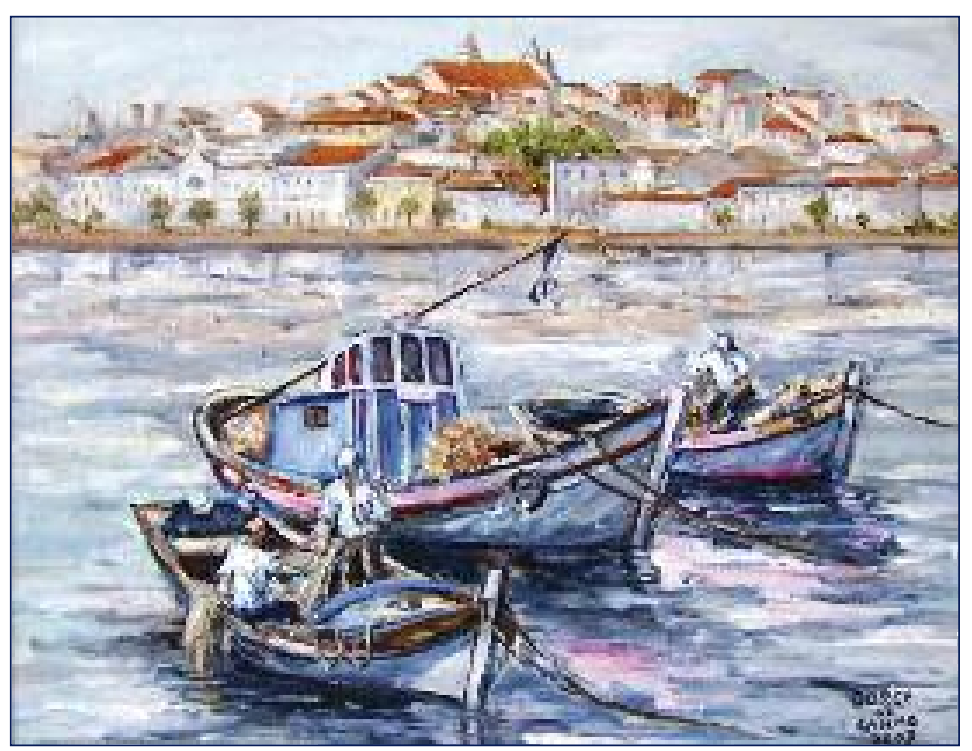

Barcos em Lagos, Algarve

Jorge do Carmo

\section{JORGE DO CARMO}

Artista autodidata, 72 anos, natural de Viseu 